\title{
Propionigenium modestum gen. nov. sp. nov. a New Strictly Anaerobic, Nonsporing Bacterium Growing on Succinate
}

\author{
Bernhard Schink and Norbert Pfennig \\ Fakultät für Biologie, Universität Konstanz, Postfach 5560, D-7750 Konstanz, Federal Republic of Germany
}

\begin{abstract}
From marine and freshwater mud samples and from human saliva new strictly anaerobic, Gram-negative, nonsporeforming bacteria were isolated growing with succinate as sole source of carbon and energy. All strains grew in defined mineral media containing at least $1 \%$ sodium chloride. Succinate was stoichiometrically transformed to propionate und carbon dioxide; the growth yield varied between 2.1 and $2.4 \mathrm{~g}$ cell dry weight per mol of succinate fermented. In addition to succinate, only fumarate, L-aspartate, L-malate, oxaloacetate and pyruvate, were utilized and were stoichiometrically fermented to propionate and acetate. Yeast extract was not fermented but enhanced growth rates and yields. Neither sulfate, sulfur, nor nitrate were reduced. The DNA base ratio was $33.9 \pm 0.3 \mathrm{~mol} \%$ guanine plus cytosine. A marine isolate, strain Gra Succ 2, is described as type strain of a new species, Propionigenium modestum gen. nov. sp. nov., in the family Bacteroidaceae.
\end{abstract}

Key words: Propionigenium modestum gen. nov. sp. nov. genus and species description - Succinate degradation Anaerobic fermentations - Energy metabolism

Succinate is an important end product of anaerobic metabolic processes, either of true fermentations or of anaerobic respirations with fumarate, malate or aspartate as external electron acceptors (Thauer et al. 1977; Stouthamer 1980; Gottschalk and Andreesen 1979). Although the redox balance of succinate is more oxidized than that of sugars, there are virtually no fermentative processes known so far by which succinate could be anacrobically degraded. In the light, phototrophic purple bacteria are able to assimilate succinate as a source of cell carbon (Biebl and Pfennig 1981). In the dark, some succinic acid-producing organisms such as Selenomonas ruminantium (Scheifinger and Wolin 1973) or Veillonella alcalescens (Yousten and Delwiche 1961) have been shown to decarboxylate succinate to propionate in a reaction not linked to energy conservation.

In the present paper a new anaerobic bacterium is described which is able to conserve energy from the conversion of succinate to propionate and grows in mineral medium with succinate as sole source of carbon and energy.

\section{Materials and Methods \\ Sources or Organisms}

The following strains were isolated in pure culture from enrichment cultures inoculated with mud samples: 1 . Strains

Offprint requests to: $\mathrm{B}$. Schink

Konstanzer Online-Publikations-System (KOPS)

URL: http://www.ub.uni-konstanz.de/kops/volltexte/2007/2510/

URN: http://nbn-resolving.de/urn:nbn:de:bsz:352-opus-25103
Gra Succ 2, Gra Succ 22, and Gra Succ 23 from black, anaerobic mud of Canale Grande, Venice, Italy. Similar isolates were also obtained from another channel in Venice (Rio Marin) and from marine black mud taken near Cuxhaven, FRG. 2. Strains Wo Succ 1 and Gö Succ 2 from mud of a creek near Konstanz and from anaerobic digestor sludge of the sewage plant in Göttingen, FRG. 3. Strains Spu Succ 3 and Spu Succ 4 from human saliva. Methanospirillum hungatei strain $\mathrm{M} 1 \mathrm{~h}$ was isolated from digested sludge of the sewage plant, Göttingen, FRG. Desulfovibrio vulgaris strain Marburg was kindly provided by Prof. Dr. R. K. Thauer, Marburg. Selenomonas ruminantium DSM 2150, ATCC 12561, Veillonella alcalescens DSM 2007, ATCC 17745, and Veillonella parvula DSM 2008, ATCC 10790, were obtained from the Deutsche Sammlung für Mikroorganismen, Göttingen.

\section{Media and Growth Conditions}

The basal medium had the following composition (values in $\mathrm{g} / \mathrm{l}): \mathrm{KH}_{2} \mathrm{PO}_{4}, 0.2 ; \mathrm{NH}_{4} \mathrm{Cl}, 0.25 ; \mathrm{KCl}, 0.5 ; \mathrm{CaCl}_{2} \cdot 2 \mathrm{H}_{2} \mathrm{O}$, 0.15 . Freshwater medium in addition contained $1.0 \mathrm{~g} \mathrm{NaCl}$ and $0.4 \mathrm{~g} \mathrm{MgCl}_{2} \cdot 6 \mathrm{H}_{2} \mathrm{O}$, marine medium $20.0 \mathrm{~g} \mathrm{NaCl}$ and $3.0 \mathrm{~g} \mathrm{MgCl}_{2} \cdot 6 \mathrm{H}_{2} \mathrm{O}$ per liter. Sodium bicarbonate, sodium sulfide, trace element solution SL 7 and vitamin solution (Pfennig 1978) were added to the autoclaved, cooled medium from sterile stock solutions as described in detail (Widdel and Pfennig 1981). The $\mathrm{pH}$ was adjusted to $7.2-7.3$. For enrichment cultures, the medium was dispensed à $50 \mathrm{ml}$ into $100 \mathrm{ml}$ serum bottles gassed with $\mathrm{N}_{2} / \mathrm{CO}_{2}$ mixture $(80 \%$ $20 \%$ ) and sealed with butyl rubber stoppers or, for pure cultures, into rubber-sealed $50 \mathrm{ml}$ screw cap bottles or $20 \mathrm{ml}$ screw cap tubes which were completely filled. Strains grew equally well in both types of cultivation vials. Substrates were added from sterile stock solutions before inoculation. Substrates were autoclaved as $0.2-0.5 \mathrm{M}(\mathrm{NaOH}-$ neutralized) solutions. Some thermolabile substrates (pyruvate, oxaloacetate, glucose etc.) were filter-sterilized.

Growth of pure cultures was followed in $20 \mathrm{ml}$ tubes in a Bausch and Lomb-Spectronic 70 spectrophotometer. In tests for syntrophic growth, excess of pure cultures of Methanospirillum hungatei or Desulfovibrio vulgaris was added; $10 \mathrm{mM}$ acetate and $10 \mathrm{mM}$ acetate plus $10 \mathrm{mM}$ sulfate, respectively, were added to these tubes. For further characterization, also commercial media systems (API $20 \mathrm{~A}$, BioMerieux, Nürtingen, FRG) were applied. Aerobic growth was tested in agar shake gradient cultures under air. Selenomonas ruminantium, Veillonella alcalescens and $V$. parvula were cultivated on special complex media (De Vries et al. 1977; Rogosa 1964).

All growth tests were carried out at least in duplicates at $28^{\circ} \mathrm{C}$ unless indicated otherwise. 


\section{Isolation}

Pure cultures were obtained by repeated application of the agar shake culture method described by Pfennig (1978). Tubes were gassed with $\mathrm{N}_{2} / \mathrm{CO}_{2}$ mixture $(80 \% / 20 \%)$ and sealed with butyl rubber stoppers. Purity was checked microscopically and also by growth tests in complex medium (AC medium, Difco Laboratories, Detroit, Michigan, USA) with and without addition of $20 \mathrm{mM}$ succinate.

Gram staining was carried out according to Magee et al. (1975) as modified by Widdel (1980) without counterstaining. An unidentified Bacillus sp. strain and Escherichia coli were used as controls.

\section{Chemical Analyses}

Sulfide formation from sulfur or sulfate was analyzed by the methylene blue method (Cline 1969). Formation of nitrite from nitrate was assayed by azo dye formation with sulfanilic acid and $\alpha$-naph thylamine. Acetate, other volatile fatty acids, alcohols and methane were assayed by gas chromatographic procedures as described (Schink and Pfennig 1982). Protein was quantified by the method of Hartree (1972).

\section{DNA Base Composition}

The mol per cent guanine plus cytosine of the DNA was determined with the thermal denaturation method according to DeLey (1970) after extraction as described by Marmur (1961).

Cytochromes were assayed in French pressure cell extracts of cells grown on a mixture of $20 \mathrm{mM}$ succinate and $20 \mathrm{mM}$ fumarate. Crude extracts as well as membrane fractions prepared by $60 \mathrm{~min}$ centrifugation at $30,000 \times g$ in a Sorvall centrifuge were subjected to difference spectroscopy in a Gilford model 250 spectrophotometer.

\section{Assay of Succinate Decarboxylating Activities}

$20.0 \mathrm{~g} \mathrm{NaCl}, 3.0 \mathrm{~g} \mathrm{MgCl}_{2} \cdot 6 \mathrm{H}_{2} \mathrm{O}, 2.42 \mathrm{~g}$ Trishydroxymethylaminomethane, $1.0 \mathrm{~g} \mathrm{NaHCO} 3,0.2 \mathrm{~g} \mathrm{CaCl}_{2} \cdot 2 \mathrm{H}_{2} \mathrm{O}, 0.5 \mathrm{~g}$ $\mathrm{KCl}, 0.2 \mathrm{~g} \mathrm{KH}_{2} \mathrm{PO}_{4}$ were dissolved in 11 of distilled water and the solution was degassed with a water suction pump. Under $\mathrm{N}_{2} / \mathrm{CO}_{2}$ atmosphere sodium sulfide solution was added to give $0.04 \%$ final concentration, and the $\mathrm{pH}$ was adjusted to 7.0 .

Succinate-grown cells were washed and resuspended in this buffer, broken in a French pressure cell at 1870 bar and the extract was separated from unbroken cells by $10 \mathrm{~min}$ centrifugation at $10,000 \times g$. The crude extract obtained was applied to $12 \mathrm{ml}$ tubes containing the same buffer and further additions from stock solutions as specified in Table 3 to a total volume of $5 \mathrm{ml}$. Tubes were gassed with $\mathrm{N}_{2} / \mathrm{CO}_{2}$ mixture and sealed with butyl rubber stoppers. Samples were withdrawn with a syringe at zero time and at intervals of 15 min up to a maximum of $120 \mathrm{~min}$, acidified with formic acid, and subjected to gas chromatographic analysis of fatty acids as described (Schink and Pfennig 1982).

\section{Results}

A 1

Enrichment, Isolation and Enumeration

$50 \mathrm{ml}$ enrichment cultures with $20 \mathrm{mM}$ succinate in either freshwater or salt water medium were inoculated with $3-5 \mathrm{ml}$ of anaerobic mud from freshwater creeks, sludge digestors, and salt water channels (Venice). Gas production started after 2-4 weeks and ceased after further 4 weeks. In subcultures on the same media turbidity developed within $3-5$ days but gas production was small and the $\mathrm{pH}$ increased from $7.2-7.3$ to 7.6-7.8. Further subcultures either in the presence or in the absence of additional Methanospirillum hungatei inocula always yielded the same types of cocci or short rods with some contaminating longer rods (Fig. 1 a). By fluorescence microscopy, no methanogenic bacteria other than Methanospirillum could be detected. Isolation was attempted in agar shake cultures with and without additional Desulfovibrio vulgaris inocula added as a hydrogen sink. In both cases similar slightly yellowish, small, smooth colonies developed which were picked with sterile Pasteur pipettes, resuspended in small amounts of anaerobic mineral medium, and again diluted in agar cultures. The resulting colonies were transferred to liquid mineral medium and checked for purity by microscopic control and by inoculation into Difco AC-medium.

Finally, one strain (Gra Succ 2) was chosen out of five for further physiological characterization.

Enumeration of succinate-degrading bacteria by the three-tube most probable number technique (American Public Health Association 1969) in mud of Canale Grande, Venice, in anaerobic digestor sludge, and in anaerobic creek mud yielded a total count of 93 cells per $\mathrm{ml}$ of mud each, the prevailing type being a coccus-like short rod similar to strain Gra Succ 2.

\section{Morphology and Cytological Properties}

All isolates, either from freshwater or marine origin, were short rods with a diameter of $0.5-0.6 \mu \mathrm{m}$ and a length varying between 0.5 and $2 \mu \mathrm{m}$. Whereas strain Gra Succ 2 often appeared like a real coccus (Fig. $1 \mathrm{a}-\mathrm{c}$ ) cells of other strains appeared more rod-shaped (Fig. $1 \mathrm{~d}$ ). In enrichments, cells occurred mostly single or sometimes in pairs (Fig. 1 a), however, after isolation in pure culture, they tended to form chains and aggregates thus often appearing as irregular long rods (Fig. $1 \mathrm{c}$ ). In aged cultures, vesicles of probably lysed cells were observed (Fig. 1c). Ultrathin sections of cells of strain Gra Succ 2 showed the non-coccoid shape of cells in a cell chain (Fig. 2a). At higher magnification, a multi-layered cell wall structure as typical for Gram negative cells was observed (Fig. $2 \mathrm{a}$ and $\mathrm{b}$ ) which confirms the results of Gram staining procedures.

Motility or spores were never detected, neither on mineral medium alone nor in the presence of additional soil extract, xylose, or manganese chloride. Pasteurized mud samples $\left(15 \mathrm{~min}\right.$, at $\left.80^{\circ} \mathrm{C}\right)$ did not yield enrichments of succinatefermenting bacteria.

The guanine plus cytosine content of the DNA of strain Gra Succ 2 was $33.9 \pm 0.3 \%$ as determined by the thermal denaturation method in three independent assays.

\section{Nutritional Properties}

All marine isolates grew well in salt water medium with succinate as sole source of carbon and energy. Strain Gra Succ 2 was not able to grow in freshwater medium and required at least $2 \% \mathrm{NaCl}$. With less $\mathrm{NaCl}$, growth was delayed, and with $1 \% \mathrm{NaCl}$, growth only occurred in the presence of at least $0.1 \%$ additional $\mathrm{MgCl}_{2} \cdot 6 \mathrm{H}_{2} \mathrm{O}$. Higher salt concentrations $\left(3 \% \mathrm{NaCl}, 0.5 \% \mathrm{MgCl}_{2}\right)$ did not inhibit 

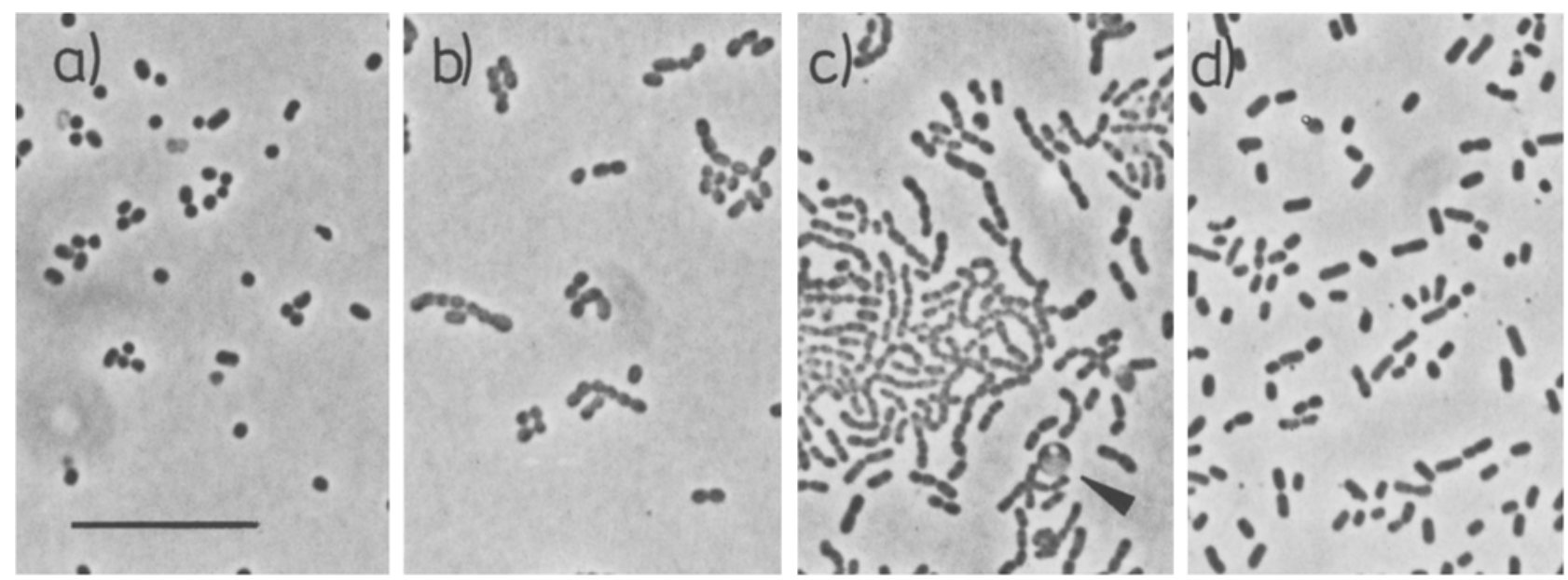

Fig. 1 a-d. Phase contrast photomicrographs of succinate-fermenting bacterial isolates grown on succinate. Bar equals $10 \mu \mathrm{m}$ in all cases. a Enrichment from anaerobic mud of Canale Grande, Venice, after four transfers. b Strain Gra Succ 2. c Aged culture of strain Gra Succ 2 showing cell chains and clumps and also vesicles of lysed cells (arrows). d Strain Gra Succ 23; both strains were isolated from Canale Grande mud
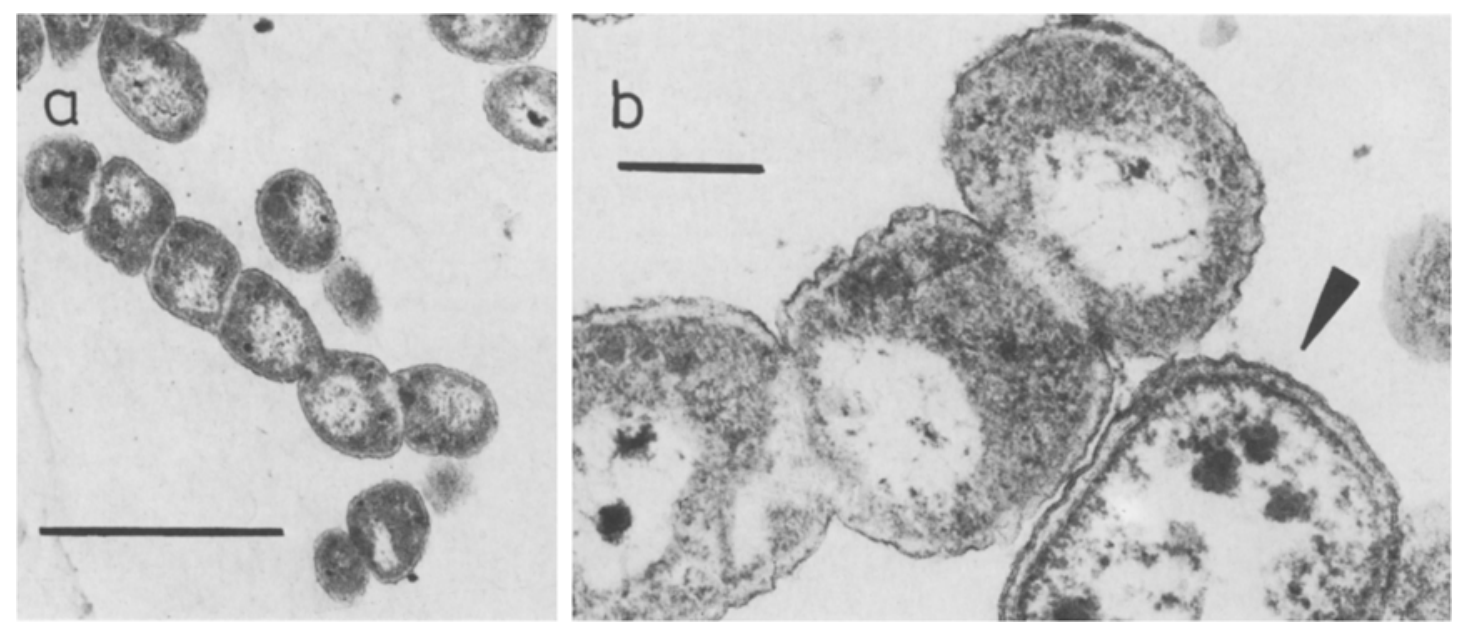

Fig. 2a and b. Electron micrographs of ultrathin sections of strain Gra Succ 2 taken by Prof. Dr. F. Mayer, Göttingen. a Cell chain in a growing culture. Bar equals $1 \mu \mathrm{m}$. b Details of cell wall structure at a higher magnification. Bar equals $0.2 \mu \mathrm{m}$

growth. The salt requirements were the same irrespective of succinate or pyruvate being used as substrates. $\mathrm{NaCl}$ could not be replaced by $\mathrm{KCl}$.

Freshwater enrichments grew well in freshwater medium and also in freshwater agar cultures, however, pure cultures could only be obtained in liquid media with at least $1 \% \mathrm{NaCl}$. Growth yields were always slightly higher in the presence of higher salt concentrations. Vitamins and the trace elements selenium, molybdenum and tungsten were present in enrichment media, however, they were not necessary for growth of strain Gra Succ 2 in salt water medium for at least 5 subsequent transfers. No growth was obtained under aerobic or microaerobic conditions. Phosphate concentrations higher than $20 \mathrm{mM}$ inhibited growth on succinate.

Substrates tested for utilization are listed in Table 1. The only substrates utilized were succinate, fumarate, L-aspartate, L-malate, oxaloacetate and pyruvate. No other mono- or dicarboxylic acids, alcohols or sugars nor yeast extract, casamino acids or peptone served as growth substrates. Growth on fumarate, malate, and aspartate started only after lag periods of $4-8$ days, but could be stimulated by the addition of small amounts $(2-5 \mathrm{mM})$ of succinate. Growth yields on fumarate or malate were not enhanced by the presence of formate or hydrogen.

\section{Physiological Properties and Fermentation Stoichiometry of Strain Gra Succ 2}

On succinate, propionate was the only detectable organic fermentation product, and it was formed in equimolar amounts to the succinate added. Growth yields correlated with the amounts of substrate given and product formed (Fig. 3) and the same correlation is also apparent from the growth curve in Fig. 4. Yeast extract enhanced growth rates and yields, however, it did not serve as energy source in the absence of succinate. Addition of $5 \mathrm{mM}$ acetate did not enhance growth rates or yields during growth on mineral medium. The maximum growth rate in mineral medium with succinate as sole carbon and energy source was $0.154 \mathrm{~h}^{-1}$ $\left(t_{\mathrm{d}}=4.5 \mathrm{~h}\right)$. In the presence of $0.1 \%$ yeast extract, growth rate and yield were enhanced $\left(\mu=0.277 \mathrm{~h}^{-1} ; t_{\mathrm{d}}=2.5 \mathrm{~h}\right)$. The optimum growth temperature was $33^{\circ} \mathrm{C}$, the temperature limits were $15^{\circ} \mathrm{C}$ and $40^{\circ} \mathrm{C}$. The $\mathrm{pH}$ optimum was at $7.1-7.7$, the $\mathrm{pH}$ limits were $\mathrm{pH} 6.5$ and 8.4. The stoichiometric 
Table 1. Substrates tested for growth and fermentation by strain Gra Succ 2. Numbers given after each substrate indicate initial concentrations in $\mathrm{mmol} \cdot 1^{-1}$

\begin{tabular}{|c|c|c|c|c|c|c|}
\hline & & Final $O D_{650}$ & & & & \\
\hline $\begin{array}{l}\text { Substrates } \\
\text { utilized: }\end{array}$ & $\begin{array}{l}\text { Succinate (20) } \\
\text { Fumarate (10) } \\
\text { L-Aspartate (10) } \\
\text { L-Malate }(10) \\
\text { Oxaloacetate }(10) \\
\text { Pyruvate }(10)\end{array}$ & $\begin{array}{l}0.21 \\
0.17 \\
0.17 \\
0.175 \\
0.28 \\
0.28\end{array}$ & & & & \\
\hline
\end{tabular}

No formation of indole from tryptophan, no hydrolysis of urea, gelatine, or esculin. No catalase activity

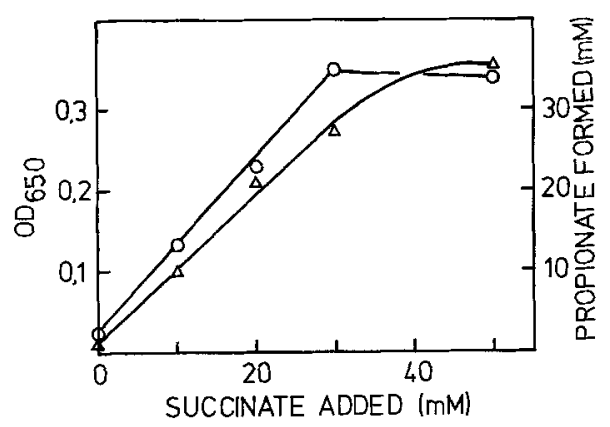

Fig. 3. Dependence of growth and propionate formation on the amount of succinate added to mineral medium inoculated with strain Gra Succ 2. $(\mathrm{O})$ Optical density, $(\Delta)$ propionate formed

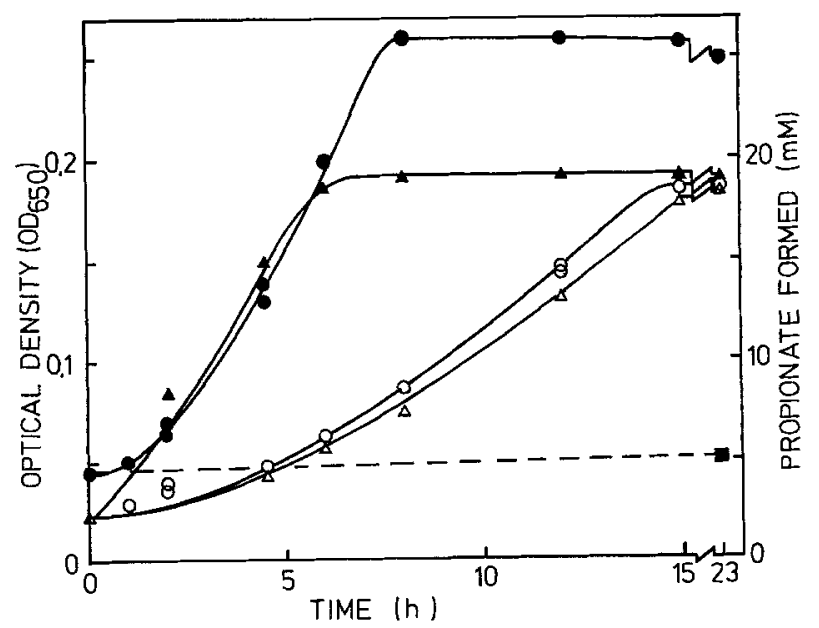

Fig. 4. Fermentation time course of strain Gra Succ 2 on succinate. Experiments were performed at $30^{\circ} \mathrm{C}$ in $20 \mathrm{ml}$ tubes sealed with Bellco rubber septa. Samples for product analysis were removed by a syringe at times indicated and the headspaces were flushed with $\mathrm{N}_{2} / \mathrm{CO}_{2}$ gas mixture. Circles: Cell density, triangles: propionate formed; open symbols refer to an experiment in mineral medium with $20 \mathrm{mM}$ succinate,

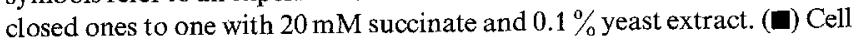
density in a yeast-extract containing tube without succinate relationships between substrate utilization, product formation, and synthesis of cell material are listed in Table 2. With succinate, propionate was the only organic fermentation product. With fumarate, aspartate, malate, pyruvate and oxaloacetate as substrates, both propionate and acetate were formed. The fermentation equations for the dissimilatory reactions can be written as follows:

for succinate:

$\mathrm{C}_{4} \mathrm{H}_{4} \mathrm{O}_{4}^{2-}+\mathrm{H}_{2} \mathrm{O} \rightarrow \mathrm{CH}_{3} \mathrm{CH}_{2} \mathrm{COO}^{-}+\mathrm{HCO}_{3}^{-}$

for fumarate :

$3 \mathrm{C}_{4} \mathrm{H}_{2} \mathrm{O}_{4}^{2-}+6 \mathrm{H}_{2} \mathrm{O} \rightarrow 2 \mathrm{CH}_{3} \mathrm{CH}_{2} \mathrm{COO}^{-}+\mathrm{CH}_{3} \mathrm{COO}^{-}$
$+4 \mathrm{HCO}_{3}^{-}+\mathrm{H}^{+}$

for oxaloacetate:

$3 \mathrm{C}_{4} \mathrm{H}_{2} \mathrm{O}_{5}^{2-}+6 \mathrm{H}_{2} \mathrm{O} \rightarrow \mathrm{CH}_{3} \mathrm{CH}_{2} \mathrm{COO}^{-}+2 \mathrm{CH}_{3} \mathrm{COO}^{-}$ $+5 \mathrm{HCO}_{3}^{-}+2 \mathrm{H}^{+}$

for pyruvate:

$3 \mathrm{C}_{3} \mathrm{H}_{3} \mathrm{O}_{3}^{-}+3 \mathrm{H}_{2} \mathrm{O} \rightarrow \mathrm{CH}_{3} \mathrm{CH}_{2} \mathrm{COO}^{-}+2 \mathrm{CH}_{3} \mathrm{COO}^{-}$ $+2 \mathrm{HCO}_{3}^{-}+2 \mathrm{H}^{+}$.

The assimilation of substrate into cell material $\left\langle\mathrm{C}_{4} \mathrm{H}_{7} \mathrm{O}_{3}\right\rangle$ was calculated as follows:

for succinate:

$$
\begin{aligned}
& 17 \mathrm{C}_{4} \mathrm{H}_{4} \mathrm{O}_{4}^{2-}+32 \mathrm{H}_{2} \mathrm{O} \rightarrow 14\left\langle\mathrm{C}_{4} \mathrm{H}_{7} \mathrm{O}_{3}\right\rangle+12 \mathrm{HCO}_{3}^{-} \\
& +22 \mathrm{OH}^{-} \\
& \text {for fumarate: } \\
& \left.17 \mathrm{C}_{4} \mathrm{H}_{2} \mathrm{O}_{4}^{2-}+42 \mathrm{H}_{2} \mathrm{O} \rightarrow 12 \mathrm{C}_{4} \mathrm{H}_{7} \mathrm{O}_{3}\right\rangle+20 \mathrm{HCO}_{3}^{-} \\
& +22 \mathrm{OH}^{-}
\end{aligned}
$$

for oxaloacetate:

$17 \mathrm{C}_{4} \mathrm{H}_{2} \mathrm{O}_{5}^{2-}+35 \mathrm{H}_{2} \mathrm{O} \rightarrow 10\left\langle\mathrm{C}_{4} \mathrm{H}_{7} \mathrm{O}_{3}\right\rangle+28 \mathrm{HCO}_{3}^{-}$ $+6 \mathrm{OH}^{-}$

for pyruvate:

$17 \mathrm{C}_{3} \mathrm{H}_{3} \mathrm{O}_{3}^{-}+18 \mathrm{H}_{2} \mathrm{O} \rightarrow 10\left\langle\mathrm{C}_{4} \mathrm{H}_{7} \mathrm{O}_{3}\right\rangle+11 \mathrm{HCO}_{3}^{-}$

$+6 \mathrm{OH}^{-}$.

Thus, $1 \mathrm{mg}$ of cell dry weight is formed from $0.0118 \mathrm{mmol}$ succinate, or $0.0137 \mathrm{mmol}$ fumarate, or $0.0165 \mathrm{mmol}$ of either oxaloacetate or pyruvate. 
Table 2. Growth yields and stoichiometry of fermentation by strain Gra Succ 2. All figures are means of at least two independent assays. Production of carbon dioxide was calculated according to the fermentation equations given in the "Results" section

\begin{tabular}{|c|c|c|c|c|c|c|c|}
\hline \multirow[t]{2}{*}{ Substrate } & \multirow{2}{*}{$\begin{array}{l}\text { Amount of } \\
\text { substrate } \\
\text { degraded } \\
\text { (mmol) }\end{array}$} & \multirow{2}{*}{$\begin{array}{l}\text { Cell dry } \\
\text { weight } \\
\text { formed } \\
(\mathrm{mg})^{\mathrm{a}}\end{array}$} & \multirow{2}{*}{$\begin{array}{l}\text { Substrate } \\
\text { assimilated } \\
(\mathrm{mmol})\end{array}$} & \multicolumn{2}{|c|}{$\begin{array}{l}\text { Products formed } \\
\text { (mmol) }\end{array}$} & \multirow{2}{*}{$\begin{array}{l}\text { Growth } \\
\text { yield } \\
\text { mg/mmol } \\
\text { substrate } \\
\text { utilized }\end{array}$} & \multirow{2}{*}{$\begin{array}{l}\text { Carbon } \\
\text { recovery } \\
\%\end{array}$} \\
\hline & & & & Propionate & Acetate & & \\
\hline Succinate & 10 & 24.6 & 0.29 & 9.7 & $<0.1$ & \multirow{2}{*}{2.46} & 99.9 \\
\hline Succinate & 15 & 36.8 & 0.435 & 14.5 & $<0.1$ & & 99.5 \\
\hline Fumarate & 1.0 & 3.8 & 0.052 & 0.59 & 0.37 & 3.8 & 101.2 \\
\hline Pyruvate & 0.5 & 3.1 & 0.051 & 0.145 & 0.32 & 6.2 & 103.2 \\
\hline Oxaloacetate & 0.5 & 3.1 & 0.051 & 0.14 & 0.315 & 6.2 & 101.2 \\
\hline
\end{tabular}

a Cell dry weights were determined directly on succinate alone in $500 \mathrm{ml}$ cultures (first two lines). The other dry weight values were calculated by comparison of cell densities reached in $50 \mathrm{ml}$ cultures. The conversion factor used was $0.1 \mathrm{OD}_{650} \stackrel{\hat{=}}{=} 3.43 \mathrm{mg}$ dry weight per 1 . Initial substrate concentrations were $20 \mathrm{mM}$ (succinate and fumarate) and $10 \mathrm{mM}$ (pyruvate and oxaloacetate)

Table 3. Activities of decarboxylation of dicarboxylic acids by cell-free extracts of strain Gra Succ 2

\begin{tabular}{|c|c|c|c|}
\hline \multirow[t]{2}{*}{ Ingredients } & \multicolumn{3}{|c|}{$\begin{array}{l}\text { Monocarboxylic acid formed } \\
\mu \mathrm{mol} \cdot \min ^{-1} \mathrm{~g} \text { protein }\end{array}$} \\
\hline & Acetate & Propionate & Butyrate \\
\hline Cell extract + succinate $20 \mu \mathrm{mol} \cdot \mathrm{ml}^{-1}$ & $<0.1$ & 4.50 & n.d. \\
\hline Cell extract + succinate $10 \mu \mathrm{mol} \cdot \mathrm{ml}^{-1}$ & $<0.1$ & 4.52 & n.d. \\
\hline Cell extract + succinate $10 \mu \mathrm{mol} \cdot \mathrm{ml}^{-1}+$ avidin $0.1 \mathrm{mg} \mathrm{m}^{-1}$ & $<0.1$ & 4.52 & n.d. \\
\hline Cell extract + succinate $10 \mu \mathrm{mol} \cdot \mathrm{ml}^{-1}+$ biotin $0.2 \mathrm{mg} \mathrm{mi}^{-1}$ & $<0.1$ & 4.36 & n.d. \\
\hline Cell extract + succinate $10 \mu \mathrm{mol} \cdot \mathrm{ml}^{-1}$ & $<0.1$ & $<0.1$ & n.d. \\
\hline Cell extract only & $<0.1$ & $<0.1$ & n.d. \\
\hline Cell extract + malonate $10 \mu \mathrm{mol} \cdot \mathrm{ml}^{-1}$ & 4.11 & $<0.1$ & n.d. \\
\hline Cell extract + glutarate $10 \mu \mathrm{mol} \cdot \mathrm{ml}^{-1}$ & $<0.1$ & $<0.1$ & $<0.1$ \\
\hline
\end{tabular}

Experiments were carried out as described in Materials and Methods. The protein content in the reaction mixture was $1.4 \mathrm{mg} \cdot \mathrm{ml}{ }^{-1}$. Reactions were linear with time for at least $1 \mathrm{~h}$. All values given are means of at least two independent assays. n.d. means not determined

The molar growth yields were $2.4 \mathrm{~g}$ dry weight with succinate, $3.8 \mathrm{~g}$ with fumarate, malate and aspartate and $6.2 \mathrm{~g}$ with both oxaloacetate and pyruvate. If combinations of either succinate and fumarate or fumarate and pyruvate or oxaloacetate were applied, the resulting yields and amounts of products formed did not give any indications for electron transfers between the respective substrates. Neither sulfate, not thiosulfate, sulfur or nitrate was reduced during growth on pyruvate. In coculture experiments with strain Gra Succ 2 and either Methanospirillum hungatei or Desulfovibrio vulgaris, no shift in the fermentation balance of succinate or pyruvate could be obtained. Hydrogen seems not to be produced or consumed by our isolate.

\section{Studies with Cell-free Extracts}

Crude extracts as well as membrane fractions prepared from cells of strain Gra Succ 2 grown on a mixture of $20 \mathrm{mM}$ succinate and $20 \mathrm{mM}$ fumarate were subjected to spectrophotometric analysis. No pigments absorbing in the range of 400 to $650 \mathrm{~nm}$ were detected, neither in air-oxidized nor dithionite-reduced extracts with a protein content of $11.8 \mathrm{mg} / \mathrm{ml}$. Redox difference spectra of dithionite-reduced minus air-oxidized extracts did not give any indication for the presence of cytochromes either.

The succinate-decarboxylating activity was also studied in crude cell extracts (Table 3). Although the activity measured was comparably low, it could be shown that it was not affected by the addition of either avidin or biotin, and that also malonate could be decarboxylated to acetate, whereas glutarate was not metabolized.

\section{Discussion}

\section{Physiology}

The new bacteria described in this paper were enriched and isolated with succinate as substrate. Fumarate, aspartate, malate, oxaloacetate and pyruvate were fermented to acetate and propionate. The growth yields on oxaloacetate and pyruvate $(6.2 \mathrm{~g} / \mathrm{mol})$ were identical and were in good agreement with the assumption of the acetate kinase reaction as sole energy-conserving phosphorylation step. Since the yields on both substrates are the same it can be concluded that the bacterium does not conserve the free energy available from the decarboxylation of oxaloacetate. The decarboxylation of oxaloacetate by Klebsiella aerogenes was reported to be catalyzed by a membrane-bound biotin-containing enzyme which simultaneously transports sodium ions across the membrane thus conserving at least part of the free energy of the decarboxylation reaction (Dimroth 1980, 1981).

The growth yields on fumarate, aspartate, and malate were all identical and were somewhat higher than that obtained on succinate ( $3.8 \mathrm{~g}$ dry weight per $\mathrm{mol}$ ). If succinate 
is an intermediate in the fermentation of fumarate to propionate and acetate no electron transport phosphorylation appears to be coupled to the reduction of fumarate. This assumption fits well to the observed lack of cytochromes and to the lack of cell yield increase when growing with both fumarate and low potential electron donors like formate or hydrogen. Addition of hemins to the medium did not enhance growth rates or yields either. Enhancement of growth rates and yields by addition of hemins to the growth medium was shown with e.g. Bacteroides fragilis (Macy et al. 1975).

The most interesting property of our new isolates is their ability to grow by degradation of succinate to propionate. The free energy change of this reaction is only small (all calculations are based on Thauer et al. 1977).

Succinate $^{2-}+\mathrm{H}_{2} \mathrm{O} \rightarrow$ Propionate ${ }^{-}+\mathrm{HCO}_{3}^{-}$ $\Delta \mathrm{G}_{0}^{\prime}=-20.6 \mathrm{~kJ} / \mathrm{mol}$.

Therefore, the decarboxylation of succinate was formerly considered to be only a non energy-conserving byreaction catalyzed by e.g. Selenomonas ruminantium (Scheifinger and Wolin 1973) Propionibacterium pentosaceum, or Veillonella alcalescens (Yousten and Delwiche 1961). With P. pentosaceum and $V$. alcalescens, the decarboxylation reaction was characterized by the same authors to be biotin- and vitamin $\mathrm{B}_{12}$-dependent.

In our hands, $V$. alcalescens showed little growth on succinate, however, since this bacterium depends on complex media, growth on succinate in comparison to succinate-free controls could not be assessed reliably.

No growth on succinate was obtained with $V$. parvula or $S$. ruminantium. Therefore, the capacity of our isolates to grow on succinate has to be considered as a new and surprising phenomenon.

The low growth yield of $2.0-2.4 \mathrm{~g}$ dry cell matter per mol of succinate metabolized is understandable in view of the small change in free energy connected to this reaction $\left(\Delta \mathrm{G}_{0}^{\prime}\right.$ $=-20.6 \mathrm{~kJ} / \mathrm{mol}$ ). This change in free energy is in the same order of magnitude as those of other decarboxylation reactions, e.g.

$$
\begin{aligned}
& \text { Oxaloacetate }^{2-}+\mathrm{H}_{2} \mathrm{O} \rightarrow \text { Pyruvate }^{-}+\mathrm{HCO}_{3}^{-} \\
& \Delta \mathrm{G}_{0}^{\prime}=-26.9 \mathrm{~kJ} / \mathrm{mol} \\
& \text { Oxalate }^{2-}+\mathrm{H}_{2} \mathrm{O} \rightarrow \text { Formate } \\
& \Delta \mathrm{G}_{0}^{\prime}=-26.8 \mathrm{~kJ} / \mathrm{mol} \\
& \text { Acetate }+\mathrm{HCO}_{3}^{-} \\
& \Delta \mathrm{H}_{0}^{\prime}=-31.1 \mathrm{OJ} / \mathrm{mol} .
\end{aligned}
$$

No organism has been shown so far to grow by the conversion of oxaloacetate to pyruvate. However, a bacterium isolated from rumen content decarboxylates oxalate to formate with a yield of $1.1 \mathrm{~g}$ dry matter per mol (Dawson et al. 1980), and the decarboxylation of acetate to methane by Methanosarcina barkeri in complex medium yields $1.6-1.9 \mathrm{~g}$ per mol (Weimer and Zeikus 1978). Our new isolates conserve energy by using even a smaller span of free energy change, and, by this, appear to be the most "modest" bacteria known so far, even more modest than the acetate-oxidizing sulfurreducing bacteria $\left(\Delta \mathrm{G}_{0}^{\prime}=-23.9 \mathrm{~kJ} / \mathrm{mol}\right)$ acetate; yield $4.0-$ $4.5 \mathrm{~g}$ dry weight per mol; Pfennig and Biebl 1976).

For long times, a free energy change lower than about $40 \mathrm{~kJ} / \mathrm{mol}$ was doubted to enable net ATP synthesis for growth as e.g. in the case of the conversion of acetate to methane and $\mathrm{CO}_{2}$ (see Zeikus 1977). However, growth on acetate was established later (Mah et al. 1978; Weimer and
Zeikus 1978); furthermore, a methanogenic bacterium was isolated that did not utilize any substrate other than acetate (Zehnder et al. 1980). In both cases, growth was very slow (doubling times 30 or $100 \mathrm{~h}$, respectively), a fact that was always understood as due to the small change in free energy of the reaction. Nevertheless, small changes in free energy do not necessary correlate with slow growth: Our succinatedegrading isolates grow faster than any acetate-degrading methanogen known so far, although they carry out an even less exergenic reaction.

As far as the energy metabolism of our new isolates is concerned, the following conclusions can be drawn from our experiments. A substrate-linked phosphorylation with biotin$\mathrm{CO}_{2}$ as energy-rich intermediate appears to be unlikely because the decarboxylation of succinate in cell free extracts was not inhibited by avidin. This result could, however, also be due to sterical hindrance at a possibly membrane-bound enzyme system. A stoichiometric synthesis of ATP can be excluded also in view of the small change in free energy of the decarboxylation reaction. We assume, therefore, that energy conservation is linked to transport processes across the cytoplasmic membrane and concomitant proton extrusions.

Zehnder and Brock (1979) suggested two models for energy conservation during acetate-dependent methane formation. For the succinate decarboxylation reaction, their models could be adapted as follows: a) The import of the dissociated dicarboxylic acid into the cell and the equivalent export of a monocarboxylic acid plus an uncharged $\mathrm{CO}_{2}$ molecule out of the cell stoichiometrically builds up a proton gradient across the cytoplasmic membrane that can drive ATP synthesis. b) The succinate decarboxylase is membranebound and couples the decarboxylation reaction with the extrusion of protons in a flip-flop manner. c) In a third model (modified after Konings and Veldkamp 1980) decarboxylation might occur in the cytoplasm but the transport of substrates and products is coupled to a net extrusion of at least one proton per molecule succinate in either a symport or antiport system. The latter two systems deserve some attention with respect to the possible involvement of sodium ions in the transport processes. As already mentioned, the decarboxylation of oxaloacetate by Klebsiella aerogenes is coupled to the extrusion of sodium ions across the membrane (Dimroth 1980). Also the decarboxylation of methylmalonylCoA by Veillonella alcalescens was shown to be associated with the generation of a sodium gradient across the cytoplasmic membrane (Hilpert and Dimroth 1982). It could be possible that transformation of succinate to propionate by our isolates occurs via methylmalonyl-CoA as intermediate. Notably, all our isolates depend on enhanced salt concentrations of at least $1 \% \mathrm{NaCl}$ in the medium which could not be replaced by $\mathrm{KCl}$. Therefore, sodium ions may be involved in translocations of substrates, products, and protons across the membrane in connection with energy conservation.

\section{Ecology}

Succinate is an important product of anaerobic degradation processes, either by direct fermentations or by anaerobic respiratory reduction of external electron acceptors like fumarate, malate or aspartate (Stouthamer 1980; Gottschalk and Andreesen 1979). The reductive anaerobic degradation of phenolic and benzoic compounds may also lead to succinate via $\beta$-oxidation of adipic acid (Evans 1977). The production of 
succinate is not confined to prokaryotes alone; protozoa and even higher organisms like the annelid Arenicola marina ferment glucose under anaerobic conditions to succinate and other acids (Zebe 1975). Often propionate is produced together with succinate by partial decarboxylation of the latter. The turnover of succinate and the simultaneous formation of propionate in the bovine rumen was determined to be $1.6 \mu \mathrm{mol} \cdot \mathrm{h}^{-1} \cdot \mathrm{g}^{-1}$ rumen content (Blackburn and Hungate 1963). Scheifinger and Wolin (1973) described a mixed culture of Bacteroides succinogenes and Selenomonas ruminantium in which the former fermented cellulose to $\mathrm{CO}_{2}$, acetate, formate, and succinate, and the latter utilized the free sugar monomers released and degraded succinate to propionate. So the formation of propionate from succinate in nature is well established and, probably carried out by many more organisms, e.g. Propionibacteria or Veillonella (Yousten and Delwiche 1961). From this point of view, the low numbers of our new isolates found at their respective

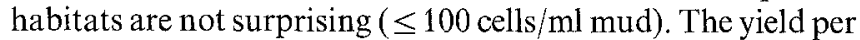
mol of succinate is low and much succinate may be decarboxylated by other less specialized organisms not able to grow with this substrate. From an ecological point of view, it does not make much difference whether a specific substrate degradation process is linked to bacterial growth or not. Moreover, no oxidation-reduction processes are connected to the decarboxylation of succinate, thus, no hydrogendependent correlations to other bacteria are established by this metabolic process. The further degradation of propionate leads to acetate and $\mathrm{CO}_{2}$ either with concomitant reduction of sulfate by e.g. Desulfobulbus propionicus (Widdel and Pfennig 1982), or in syntrophic association of a hydrogen-consuming methane bacterium and e.g. Syntrophobacter wolinii (Boone and Bryant 1980). Our sulfate-free enrichment cultures on succinate promptly also converted propionate to methane and $\mathrm{CO}_{2}$ if incubated for longer times. So the complete anaerobic degradation of succinate to either $\mathrm{CO}_{2}$ and sulfide or $\mathrm{CO}_{2}$ and methane needs at least three or four different organisms, respectively, including the respective acetatedegrading bacteria.

One comment on the salt requirement of our isolates appears necessary. The best growing strain, Gra Succ 2, was isolated in salt water medium from a marine sediment. Enrichments in fresh water medium grew to some extent in mixed culture but isolation of the respective organisms was only possible if media containing at least $1 \%$ sodium chloride were used. Failure to isolate succinate-fermenting anaerobes in freshwater medium was also reported from other laboratories (H. Veldkamp, personal communication), Succinatefermenting isolates could also be obtained in the present study in saltwater medium enrichments from saliva. Apparently, in nature and also in enrichment cultures, other microorganisms or substances may cover the requirements for charged groups which in pure culture have to be supplied by higher salt concentrations. Higher yields and shorter lag periods with marine as compared to freshwater isolates and media were recently observed also in case of other bacteria living on substrate conversions with small free energy changes (Widdel and Pfennig 1981; Schink and Pfennig 1982).

\section{Taxonomy}

The taxonomic assignment of our new isolates is difficult. As obligately anaerobic, Gram-negative, non-sporing cocci or short rod shaped bacteria they should either be assigned to the
Veillonellaceae or the Bacteroidaceae (Buchanan and Gibbons 1974).

If the cell shape of the new isolated is considered to be coccoid - and strain Gra Succ 2 resembles very much a coccus, particularly in young cultures - assignment to the Family Veillonellaceae would be most appropriate. Indeed, the strain resembles the type species of Veillonella, $V$. alcalescens, in its ability to decarboxylate succinate, the inability to ferment carbohydrates, and the formation of acetate and propionate as sole fermentation products. However, the genus Veillonella so far only comprises fastidious commensals isolated from intestinal cavities of higher animals, and all are regarded as dependent on quite complex media (Rogosa 1964, 1974; Mays et al. 1982). They also differ from our isolates by clearly coccoid cell shape, cytochrome content and capacity to reduce nitrate.

If the new isolates are recognized as short rods - and actually none of our strains has unequivocally real coccusshaped cells - they have to be assigned to Bacteroidaceae. However, lack of carbohydrate fermentation with the production of complex mixtures of several fatty acids or succinate does not allow assignment to any of the genera and affiliated groups of the Bacteroidaceae, namely Bacteroides, Fusobacterium, Leptotrichia, Butyrivibrio, Succinivibrio, Succinimonas, Lachnospira, Selenomonas, or Pectinatus (Lee et al. 1978). As Gram-negative propionate-forming bacteria the new isolates resemble the genus Propionispira, however, they differ from the elongated, curved cells of the type strain, $P$. arboris (Schink et al. 1982) by cell shape, lack of carbohydrate fermentation, and lack of cytochromes. It appears necessary, therefore, to establish a new genus and species for the nonfastidious propionate-forming short rods. Strain Gra Succ 2 is proposed as type strain of Propionigenium modestum, in the family Bacteroidaceae.

Genus Propionigenium gen. nov. Pro.pi.o.ni.ge'ni.um. M.L.n. acidum propionicum propionic acid; L.v. genere, gignere make, produce; Propionigenium M.L. neutr. n. a propionic acid producer.

Rod-shaped to coccoid Gram-negative bacteria with rounded ends, single, in pairs, or in chains. Endospores not formed.

Chemoorganotrophic metabolism fermentative. Propionate main fermentation product. Strictly anaerobic. Media containing a reductant are necessary for growth.

Habitats: Anaerobic muds of freshwater or marine origin; also occurring as commensals of higher animals.

Propionigenium modestum sp. nov. mo.de'stum L.adj. modestus modest, referring to an extremely modest type of metabolism.

Rod-shaped to coccoid cells, $0.5-0.6 \times 0.5-2.0 \mu \mathrm{m}$ in size, with rounded ends, single, in pairs, or in chains. Nonmotile, Gram-negative, non-sporeforming.

Strictly anaerobic chemoorganotroph. Succinate, fumarate, malate, aspartate, oxaloacetate, and pyruvate utilized for growth and fermented to propionate, (acetate), and $\mathrm{CO}_{2}$. No other organic acids, no sugars or alcohols metabolized. Sulfate, sulfur, thiosulfate, or nitrate not reduced. Growth requires mineral media with a reductant and at least $1 \%$ sodium chloride. Indole not formed, gelatin or urea not hydrolyzed. No catalase activity.

Selective enrichment in $\mathrm{NaCl}$-containing mineral media with succinate as substrate.

$\mathrm{pH}$ range: $6.5-8.4$, optimum at $7.1-7.7$. 
Temperature range: $15-40^{\circ} \mathrm{C}$, optimum growth temperature $33^{\circ} \mathrm{C}$. No cytochromes detectable.

DNA base ratio: $33.9 \mathrm{~mol} \% \mathrm{G}+\mathrm{C}$ (thermal denaturation).

Habitats: Anaerobic muds of freshwater and marine origin; human saliva.

Type strain: Gra Succ2, DSM 2376, deposited in Deutsche Sammlung von Mikroorganismen, Göttingen.

Acknowledgements. The authors thank Prof. Dr. Frank Mayer and his coworkers for the electron microscopic characterization of the new isolates. Technical help by Waltraut Dilling, Elisabeth Kayser and Thomas Munsch and stimulating discussions with Dr. Fritz Widdel and Dr. Georg Fuchs are gratefully acknowledged. This work was supported by a grant of the Deutsche Forschungsgemeinschaft.

\section{References}

American Public Health Association Inc., Ed (1969) Standard methods for the examination of water and wastewater including bottom sediments and sludge. New York, pp 604-609

Biebl H, Pfennig N (1981) Isolation of members of the family

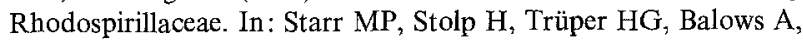
Schlegel HG (eds) The prokaryotes, a handbook on habitats, isolation, and identification of bacteria. Springer, Berlin Heidelberg New York, pp 267-273

Blackburn TH, Hungate RE (1963) Succinic acid turnover and propionate production in the bovine rumen. Appl Microbiol 11:132135

Boone DR, Bryant MP (1980) Propionate-degrading bacterium, Syntrophobacter wolinii sp.nov.gen.nov., from methanogenic ecosystems. Appl Environ Microbiol 40:626-632

Buchanan RE, Gibbons NE (1974) Bergey's manual of determinative bacteriology, 8th ed. Williams and Wilkins Co, Baltimore

Cline JD (1969) Spectrophotometric determination of hydrogen sulfide in natural waters. Limnol Oceanogr 14:454-458

Dawson KA, Allison MJ, Hartman PA (1980) Isolation and some characteristics of anaerobic oxalate-degrading bacteria from the rumen. Appl Environ Microbiol 40:833-839

DeLey J (1970) Reexamination of the association between melting point, buoyant density and the chemical base composition of deoxyribonucleic acid. J Bacteriol 101:738-754

De Vries W, Rietveld-Struyck TRM, Stouthamer AH (1977) ATP formation associated with fumarate and nitrate reduction in growing cultures of Veillonella alcalescens. Antonie van Leeuwenhoek, J Microbiol Serol 43:153-167

Dimroth P (1980) A new sodium-transport system energized by the decarboxylation of oxaloacetate. FEBS Lett 122:234-236

Dimroth P (1981) Characterization of a membrane-bound biotincontaining enzyme: Oxaloacetate decarboxylase from Klebsiella aerogenes. Eur J Biochem 115:353-358

Evans WC (1977) Biochemistry of the bacterial catabolism of aromatic compounds in anaerobic environments. Nature (London) 270:1722

Gottschalk G, Andreesen JR (1979) Energy metabolism in anaerobes. In: Quayle JR (ed) International review of biochemistry. Microbial biochemistry, vol 21 . University Park Press, Baltimore, pp 85-115

Hartree EF (1972) Determination of protein: a modification of the Lowry method that gives a linear photometric response. Anal Biochem 48:422-427

Hilpert W, Dimroth P (1982) Conversion of the chemical energy of methylmalonyl-CoA decarboxylation into a $\mathrm{Na}^{+}$gradient. Nature $296: 584-585$

Konings WN, Veldkamp H (1980). Phenotype responses to environmental change. In: Ellwood DC, Hedger JN, Latham MJ, Lynch JM, Slater JH (eds) Contemporary microbial ecology. Academic Press, London, pp $161-191$

Lee SY, Mabee MS, Jangaard NO (1978) Pectinatus, a new genus of the family Bacteroidaceae. Int J Syst Bacteriol 28:582-594
Macy J, Probst I, Gottschalk G (1975) Evidence for cytochrome involvement in fumarate reduction and adenosine 5 -triphosphate synthesis by Bacteroides fragilis grown in the presence of hemin. $\mathbf{J}$ Bacteriol 123:436- 442

Magee CM, Rodeheaver G, Edgerton MT, Edlich RF (1975) A more reliable Gram staining technic for diagnosis of surgical infections. American J Surgery 130:341 - 346

Mah RA, Smith MR, Baresi L (1978) Studies on an acetate-fermenting strain of Methanosarcina. Appl Environ Microbiol 35:1174-1185

Marmur J (1961) A procedure for the isolation of deoxyribonucleic acid from microorganisms. $\mathrm{J}$ Mol Biol 3:208-218

Mays TD, Holdeman LV, Moore WEC, Rogosa M, Johnson JL (1982) Taxonomy of the genus Veillonella Prévot. Int J Syst Bacteriol $32: 28-36$

Pfennig N (1978) Rhodocyclus purpureus gen. nov. and sp. nov., a ringshaped, vitamin $B_{12}$-requiring member of the family Rhodospirillaceae. Int J Syst Bacteriol 28:283-288

Pfennig N, Biebl H (1976) Desulfuromonas acetoxidans gen. nov. and sp. nov., a new anaerobic, sulfur-reducing, acetate-oxidizing bacterium. Arch Microbiol 110:3-12

Rogosa M (1964) The genus Veillonella. I. General cultural, ecological, and biochemical considerations. J Bacteriol 87:162-170

Rogosa M (1974) Gram-negative anaerobic cocci. In: Buchanan RE, Gibbons NE (eds) Bergey's manual of determinative bacteriology, 8 th ed. Williams and Wilkins, Baltimore, pp 445-449

Scheifinger CC, Wolin MJ (1973) Propionate formation from cellulose and soluble sugars by combined cultures of Bacteroides succinogenes and Selenomonas ruminantium. Appl Microbiol 26:789-795

Schink B, Pfennig N (1982) Fermentation of trihydroxybenzenes by Pelobacter acidigallici gen.nov.sp.nov., a new strictly anaerobic, non-sporeforming bacterium. Arch Microbiol 133:195-201

Schink B, Thompson TE, Zeikus JG (1982) Characterization of Propionispira arboris gen. nov.sp.nov., a nitrogen-fixing anaerobe common to wetwoods of living trees. J Gen Microbiol (in press)

Stouthamer AH (1980) Electron transport linked phosphorylation in anaerobes. In: Gottschalk G, Pfennig N, Werner H (eds) Anaerobes and anaerobic infections. Fischer, Stuttgart New York, pp 17-29

Thauer RK, Jungermann K, Decker K (1977) Energy conservation in chemotrophic anaerobic bacteria. Bacteriol Rev 41:100-180

Weimer PJ, Zeikus JG (1978) Acetate metabolism in Methanosarcina barkeri. Arch Microbiol 119:175-182

Widdel F (1980) Anaerober Abbau von Fettsäuren und Benzoesäure durch neu isolierte Arten Sulfat-reduzierender Bakterien. Diss Univ Göttingen

Widdel F, Pfennig N (1981) Studies on dissimilatory sulfate-reducing bacteria that decompose fatty acids. I. Isolation of new sulfatereducing bacteria enriched with acetate from saline environments. Description of Desulfobacter postgatei gen.nov.sp.nov. Arch Microbiol 129:395-400

Widdel F, Pfennig N (1982) Studies on dissimilatory sulfate-reducing bacteria that decompose fatty acids. II. Incomplete oxidation of propionate by Desulfobulbus propionicus gen.nov.sp.nov. Arch Microbiol 131:360-365

Yousten AA, Delwiche EA (1961) Biotin and vitamin $B_{12}$ coenzymes in succinate decarboxylation by Propionibacterium pentosaceum and Veillonella alcalescens. Bacteriol Proc 61:175

Zebe E (1975) In vivo-Untersuchungen über den Glucose-Abbau bei Arenicola marina (Annelida, Polychaeta). J Comp Physiol 101:133145

Zehnder AJB, Brock TD (1979) Biological energy production in the apparent absence of electron transport and substrate level phosphorylation. FEBS Lett 107:1-3

Zehnder AJB, Huser BA, Brock TD, Wuhrmann K (1980) Characterization of an acetate-decarboxylating, non-hydrogenoxidizing methane bacterium. Arch Microbiol 124:1-11

Zeikus JG (1977) The biology of methanogenic bacteria. Bacteriol Rev $41: 511-541$

Received July 21, 1982/Accepted November 11, 1982 